\title{
Globalization processes in the sphere of socio- economic and environmental relations
}

\author{
Liudmyla Orochovska ${ }^{1, *}$ and Uliana Koshetar $^{1}$ \\ ${ }^{1}$ National Aviation University, 03058, 1 Lyubomir Guzar, Kyiv, Ukraine
}

\begin{abstract}
The article examines the impact of the fourth information revolution on society, the formation of a certain social and economic system as a result of the influence of the latest information and communication technologies and changes in the human habitat. Globalization processes in the economy have become possible due to information technologies. The latter ensures the movement of capital to any continent, leveling state borders, sovereignty, the national identity of peoples. Business entities, due to the emergence of electronic media, have become able to introduce new forms and methods of economic activity that contribute to the optimization of sales of goods and services and the efficiency of production organization processes. Due to the transformation processes in the field of social and economic relations of the network society, the ability to respond quickly to changes in the world politics stances and markets of basic economic resources has been updated. As a result, the network society represents economy virtualization, the introduction of e-business, global online commerce. The change in the conditions and nature of management and labor was influenced by Internet media, which gives grounds to characterize the network society as a society of services.
\end{abstract}

\section{Introduction}

With the advent of electronic media in the late 20th century, much of the traditional functions of oral and print communication are being replaced by new ones, which are carried out through multimedia interactive means, primarily the Internet. In the globalized communication space, computer technologies and Internet networks have an impact on various spheres of life of the society, become direct participants in the formation of both the individual and society as a whole, they are actively used in areas that bring commercial profits: cinema, television, music videos, advertising and PR agencies, trade, finance, etc. Due to the acceleration of information and communication flows, capital movement, trade circulation, production chains, technology transfer, mass tourism, labor migration, and scientific communication have begun to penetrate freely through the borders of nation states. The Internet and cellular communications have become the types of mass media that have increased the speed of information, financial and economic flows, the availability of information on a global scale.

\footnotetext{
*Corresponding author: ola-2011@ukr.net
} 
Works by D. Bell [1], J. Habermas, M. Castells [2], N. Kirillova [3], N. Luhmann [4], A. Toffler [5], and others are dedicated to the research on the role of information technologies and networks as a social transformer. They point out that as a result of the societal transformation under the influence of new information technologies, the disintegration of established social ties and relationships occurs, and there takes place the formation of a new type of social and economic relations based on networks.

The role of global innovation networks in the development of the modern world economy, in promotion of the international cooperation in the sphere of innovations, transfer of knowledge into the global economy and the overall scientific and technological development, the importance of Networks in the process of commercialization and automation of office accompaniment are being studied by Ukrainian scientists Y. Liubyvyi [6], V. Liakh [7], L. Drotianko [8], L. Orokhovska [9], V. E. Polivanov [10], and others. In their studies, their attention is drawn to certain aspects of the impact of informatization on the social and economic transformations in society. This study is dedicated to identifying general trends in transformation processes in the system of international economic relations under the influence of new information technologies.

\section{Materials and methods}

Based on the systemic, cultural-historical, and socio-cultural approaches, there has been performed theoretical interpretation of the transformations of international economic relations, which are determined by new information and communication technologies. The theoretical and methodological basis of the study contains general and specific techniques and approaches that allowed to analyze the main processes in the field of social and economic relations of the network society.

The systemic approach allowed us to consider the social and economic interactions of the network society within globalistics and provided for studying the problems by means of a large number of methods. The hermeneutic method was used to understand and explain texts on social and economic issues. Methods of retrospective modeling and comparative conceptual analysis were applied to analyze conceptual invariants and compare ideological models of texts and topics of discussion. This allowed us to take into account the integrity and dynamics of the network society and its impact on the human factor in the formation of the social and economic paradigm of the globalized world.

The structured approach allowed us to study the impact of the fourth information revolution on society as a system. Analysis of the way of thinking, perception, and understanding within the philosophical discourse was enabled due to the cognitive approach. The synergetic approach emphasized the possibility of self-organization of the network society.

\section{Results}

The spread of computers, the Internet, and cellular communication marks the fourth information revolution, which became a new milestone in the transformation of social relations as a result of radical changes in information processing associated with the invention of microprocessor technology. These changes gave rise to calling modern society a "network society" (M. Castells). The social system of such a society is based on networks that consume the information provided by microelectronic devices and communication technologies. Tim Berners-Lee's invention of the WWW network allowed, thanks to the concepts of URL, HTTP, HTML, to move from site to site, distribute information overcoming the conditional borders of countries. This contributed to the creation of new projects, services, and types of 
communication. Historically, networks had existed earlier, but before the revolution in microelectronics, according to M. Castells, they were inferior to vertical hierarchical organizations. The mentioned is explained by the fact that, by overcoming a certain limit, networks had a less efficient mode of organization, partly due to the time required for communication throughout the whole network [2].

The Internet provides high efficiency, the ability to quickly replace information, its instant distribution, total coverage. The network unites organizations, enterprises, states, public associations. Electronic media have created the conditions for the formation of new communities, both nationally and internationally. Networks have become a means to create global structures in various spheres of life of the society: economy, culture, politics.

Financial globalization, the intensification of world trade, the trend towards convergence, consolidation of international economic relations, the formation of global markets, the process of targeting the productive forces on common standards, appearance of "technological macrosystems" in the areas of communications, transport, production wouldn't be possible without the functioning of Networks. The advanced information technologies created possibilities for the formation of global TNCs and enhancement of their competitiveness. At the same time, globalization is challenging national enterprises. Globalization processes in the economic sector lead to constant changes in the methods of enterprise management and the constant dynamics of market conditions of the economy. This requires an immediate response of economic entities to market changes and adequate and balanced policies to maintain the acquired positions.

The development of electronic means of communication facilitates the almost instantaneous movement of capital to any region of the planet, which in the pursuit of income, in fact, eliminates state borders, sovereignty, the national identity of peoples. New technologies and communications, having created transnational production, changed the world market. "The global electronic banking network, which was unthinkable prior to computers and satellites, now instantly connects Hong Kong, Manila, or Singapore with the Bahamas or New York," A. Toffler writes [5]. Money ceases to be tied to the real sector of the economy, to material production. Finance turns into speculative capital, which has almost nothing to do with the production of goods and services. Money and credits are going beyond the control of individual states and can be transferred to any location in the world. Informational technologies have provided an opportunity to develop "e-commerce" as an economic activity carried out with the use of computer networks and including the following: e-commerce; electronic data interchange (EDI); electronic funds transfer (EFT); e-cash; emarketing; e-banking; e-insurance; e-mail, facsimile communication, data transmission systems from computer to fax, e-catalogs, bulletin board systems (BBS), Intranet (exchange of information within the company), Extranet (exchange of information with the outside world), etc. [10].

Business entities, thanks to global networks, have received the opportunity to act quickly and efficiently, instantly respond to markets of key economic resources and the changes in stances of world politics. Virtual economy and e-business have become the reality of our time, with the latter, according to the characteristics by Y. Liubyvyi, being "a transition to a certain social and economic formation, metacapitalism with electronic metamarkets and an international network of electronic shops-metamarkets" [6].

Large financial markets have switched to round-the-clock online trading in real time, with access from anywhere in the world. Also, in the network society, digital technologies have become the basis of the supply chain. Accordingly, it sets the task for transport companies to carry out their obligations on mutually beneficial terms. The above-mentioned will ensure the adaptation of companies to the dynamic environment and coordinate the balance among the economic, industrial, and public interests of the globalized world. 
A qualitative characteristic of the information society is such an indicator as the employment of the working population in the field of production, processing, management, and information exchange. Only with the development of scientific and technological progress, the processes of obtaining and distributing knowledge have become a mass phenomenon, and, at the turn of the 21 st century, the knowledge economy has been formed, the essence of which is that knowledge becomes a decisive factor in production and professions with a predominance of intellectual labor account for an increase in employment: $85 \%$ in the US, $90 \%$ in Japan [3].

Significant changes in production processes were caused by computerization, which had the greatest impact on the activities of "white-collar workers" and managers, who began to view society from the standpoint of "machines for the production of wealth." If before only brokers created wealth by manipulating stocks, nowadays manipulating information as a means of creating wealth is no longer a monopoly of stock exchange players. Now every engineer and the entire communications industry are involved in it to the same extent. Thus, the emergence of electronic media leads to the introduction of new forms of economic activity, new methods of the organization of production and sale of goods and services. It is not so much things as symbols and codified knowledge that are becoming the value of this virtual economy.

New media are also changing the nature and conditions of labor. The information (postindustrial) society was characterized by D. Bell as a society of services: "Post-industrial society is based on services. Therefore, it is a game between people. The main thing is no longer about muscle strength and energy, but information. The main actor is now a professional, because their education and experience allow them to meet all the requirements of post-industrial society" [1]. According to D. Bell, the nature of labor in modern society is changing in two ways. Firstly, modern production requires highly skilled labor. Instead of working at large enterprises subject to the rhythm of the conveyor, modern employees work at small firms where labor has no such significant alienation as at factories. Secondly, modern labor, primarily within the service sector, is the labor related to human communication, interaction, agreement, from the flight ticket seller to the work of university professors. "Revolutions in the field of transport and information transfer, which are a consequence of the development of technology, have created new economic relationships and new social interactions" [1]. The fact that human labor now consists more of conversation with others than of interaction with the machine is fundamental to the characterization of labor in the post-industrial society.

Thanks to Internet networks, the organizational principles that underlie the management of labor and social processes are changing. The interactivity provided by the Network gives an opportunity to establish interaction in real or selected time with all participants of the production process (suppliers, customers, subcontractors, and employees), provides a higher level of coherence between business partners. The use of information and communication technologies allows us to give a new shape to our daily schedules and even our concept of time. Computers have made flexible work schedules possible. They allow employees to access data and apply changes to them both synchronously and asynchronously. With the development of the Internet, the need for giant social and economic and political structures has disappeared. Information technologies have allowed to replace mass standardized production with a system of informatized production and switch to small centralized enterprises, to local grassroots structures. The end product of such production is no longer millions of identical standardized goods but individual consumer products and services. The best way to organize such production and labor is now adhocracy (from Latin ad hoc, "according to the circumstances"), which means a temporary, situational organization aimed at solving any specific task, the implementation of a specific project where each 
organizational component is a free module and interacts with the other components of the organization not only vertically but also horizontally.

Decisions made by adhocracy, like goods and services, are destandardized. Labor for most people becomes variable, destandardized, non-repetitive and responsible, requires the individual's ability to freedom of action, independent decision-making, evaluation and judgment, constant willingness to change the employment sector, profession. But this quality of work also creates a psychological burden, stress, fear of being unemployed because you are "outdated," "left behind," "late." We should also mention here that the high level of innovation, speed of change, and unpredictability, non-standardization of the social context does not allow an individual to develop a stable orientation in the world, to control the flow of life, does not indicate the meaning of life. A person who lives in a fragmented world and is constantly exposed to technological aggression is not able to integrate and comprehend their experience of existence in the world. At the same time, there is a process of minimizing labor; thanks to new technologies, society produces more and more wealth while spending less and less labor. There is an increase in not only the number of "potential unemployed" but also the number of people who do not have a "permanent place" in society.

\section{Discussion}

The change in the organization of labor in the information society accelerates the destruction of class, corporate, professional identity leading to a change in the social order, which used to be the guarantor of stability, acted as a system of orientations. If in industrial society the system of production dominated, where everyone had their place and their system of roles within the regulated, hierarchized group, which created inseparable unity with other social subsystems, supported and consolidated them, then in post-industrial society instead of centralization there is regionalization, hierarchization and bureaucratization are replaced with democratization, instead of competition there comes unbundling, instead of standardization we have individualization. In the post-industrial era, when there is an orientation to innovation, to the application of creative discoveries of individuals, various talents and abilities of people are in demand. That is, there is a change in the "social character" of human in the information society, as rightly pointed out by V. Liakh: "Social and economic factors of the post-industrial society encourage people to be more independent in decision-making, require creative dedication, original, non-standard approaches" [7]. Thus, electronic media, as a means of activating intellectual activity, increase opportunities for creative selfexpression of the individual and stimulate the tendency to form an individualistic position among employees.

The structure of the Internet determines a new model of interpersonal interaction, accompanied by changes in the production system that requires more and more individualized workers. In place of the hierarchical way of organizing production comes a structure with no power elite, no pyramid but with an operational interaction of structural nuclei, each of which, with full individual responsibility and freedom of decision-making, performs its own set of actions. The nuclei are interconnected within a common organized structure, able to replace each other and exchange functions.

Exploring the society as a system, N. Luhmann rightly noted that even though the information society is decentralized, it closely "communicates globally through its networks; this trend, thanks to computerization, will certainly only grow in the near future" [4]. This system of communications is operationally closed and expands or shrinks depending on the number of existing communications within it. The communication space allows us to simultaneously include a significant number of communicators in different chats and forums that unite certain target groups with relevant interests. Communication through electronic media is increasingly displacing oral communication, even within a single organization. 
Although colleagues may be in adjoining rooms, they often prefer electronic communication. Often this choice is made not so much to save time but to avoid conflicts in solving complex issues related to both production activities and personal problems.

This requires adherence to the paradigm of sustainable development and the transition of civilization to a state of global dynamic equilibrium. In the formation of social and economic relations of the network society, it is necessary to take into account the interests of the entire world community. It is worth considering the instructions of one of the founders of the Club of Rome, E. Pestel, who noted that the future of the world correlates with the implementation of the idea of organic growth [11]. The latter assumes that one part (subsystem) does not grow at the expense of the others; therefore, systemic interdependent progressive development is possible. Such development of the world community should provide equal opportunities on a global scale. Each local community of the network society should discuss and coordinate the objectives in the social and economic sphere, providing harmonious and consistent solutions to major civilizational differences. Mobility and flexibility will allow avoiding those interactions that cause perturbations and let them build their own course, despite the unexpected impacts and changes [9].

S. Yahodzinskyi and L. Drotianko believe that the prospects for the development of the global space of intercultural interaction are quite optimistic, as new technical and technological tools, new information technologies are designed primarily for social and economic progress, establishing a polylogue based on mutual trust and mutual benefit [8].

\section{Conclusions}

Progress in the field of media not only expands the communicative space, information and communication links between all subsystems of the social environment but also leads to its radical transformation. Changing technologies creates a change in the way of communication that dominates in society and leads to a change in the human environment, the formation of a certain social and economic system. The information revolution, which began in the late 20th century, has become the driving force of the new stage of integration processes, i.e., globalization. It is the modern means of communication that have made it possible to really ensure the unity of the economic, political, and cultural life of the peoples. Globalization opens up enormous opportunities for humanity in expanding the exchange of goods, services, information, technology, and capital, promotes cooperation in the humanitarian sphere, leads to the enrichment of cultures. The impact of globalization significantly changes the nature of production and labor, level of knowledge, the social and professional composition of society, living conditions, the lifestyle of most people on the planet, which necessitates further research on the influence of informatization on various aspects of life of the society.

\section{References}

1. D. Bell, The Coming Post-Industrial Society: An Experience of Social Forecasting (Moscow: Akademiya, 1999)

2. M. Kastels, Internet galaxy. Worldwide Internet, Business and Suspension (Kyiv: «Vidavnictvo «Vakler» u formi TOV, 2007)

3. N.B. Kirillova, Media management as an integrating system (Moscow: Akademicheskij Proekt, 2008)

4. N. Luman, Society Society. Part I. Society as a social system (Moscow: Logos, 2004)

5. E. Toffler, Third wave (Moscow: OOO «Firma «Izdatelstvo AST», 1999) 
6. Ya.V. Lyubivij, Global informational suspension: synergetic and virtual conceptual development (Kyiv: TOV «HHI stolittya: dialog kultur», 2009)

7. V.V. Lyah, Nowadays, informational suspension: a new world of people (Kyiv: TOV «HHI stolittya: dialog kultur», 2009)

8. L. Drotianko, S. Yahodzinskyi, Information environment as the intercultural communication space https://www.matec conferences.org/articles/matecconf/abs/2017/20/matecconf_spbw2017_01006/matecco nf_spbw2017_01006.html https://doi.org/10.1051/matecconf/201710601006

9. L. Orochovska, U. Koshetar, Ideas of the cosmism philosophy natural-scientific direction within media space and social-economic space, /https://www.e3sconferences.org/articles/e3sconf/abs/2019/61/e3sconf_itese18_04035/e3sconf_itese18_ 04035.html https://doi.org/10.1051/e3sconf/201913504035

10. V.Ye. Polivanov, N.O. Dmitriyeva, Economic situation and genesis of the world electronic business, Current problems of international visions: Collection of scientific works, Kyiv: Taras Shevchenko National University of Kyiv 134, 111-129 (2018)

11. E. Pestel, Beyond the Limit to Growth (M.: Progres, 1988) 